\title{
The Analysis and Design Marketplace Information Systems Web-Based of Electronic Repair Service Providers with Haversine Method
}

\author{
Darmayana Putra $^{1)}$, Benny Daniawan ${ }^{2)}$, Suwitno $^{3)}$, Andri Wijaya ${ }^{4)}$ \\ ${ }^{122334)}$ Buddhi Dharma University \\ Jalan Imam Bonjol No. 41 Karawaci Ilir, Tangerang, Indonesia \\ ${ }^{1)}$ darmayana.putra29@gmail.com
}

Article history:

Received 15 October 2019;

Revised 20 October 2019;

Accepted 25 October 2019;

Available online 30 October 2019

Keywords:

Service Center

Haversine

Repair

BVA

UAT

\section{Abstract}

This system is designed to help customers find electronic service centers were spread in Tangerang. The distribution of electronic service center makes it difficult for users to determine the right electronic service center. Sometimes customers don't know the results of repairs from the electronic service center. Search for electronic service center on the system is using the Haversine method. Haversine is used to calculate the distance between the position of the customer and the position of the electronic service centers. In addition to Haversine, the search for electronic service center will be adjusted to the type of goods you want to repair and rating from the results of the performance electronic service center. In this system, the customer can choose the damage diagnosis available and the customer can also make a special order by describing the customer's damage. This system was tested using Black Box Testing with Boundary Value Analysis technique, based on the results of testing the system can use data with a success percentage of $96.66 \%$. The system is tested with User Acceptance Testing to find out how much the level of user acceptance of the system designed, and the result is $75 \%$ of users agree with the system.

\section{INTRODUCTION}

In this globalization era, technology helps a lot of human activities, especially in the business side, one of which is E-Commerce. E-Commerce is the sale or purchase of goods and services, with companies, households, individuals, governments, and communities that are done through computers on the internet network [1]. E-Commerce is also one form of E-Business, E-Business is an example of an internet technology-based strategy that can help businesses to communicate and distribute goods and services to consumers [2]. Every business wants to serve its customers to the maximum so that it will trigger customers to make repeated transactions. With maximum service, of course, there is a process of determining customer patterns and questionnaire ratings or reviews given to customers of services provided so that it will be able to produce services that are appropriate and maximum.

Repair is an activity to repair an item which has a damaged component. When a customer's favorite electronics are damaged, customers will want their favorite items to be reused. The electronic service center is a solution to repair electronic goods that have damage to parts or do not work well for these electronic goods. The spread of electronic service centers both large and small will certainly make it difficult for customers to determine the exact location of the electronic service center. The large electronic service centers certainly only reach one particular brand and cannot repair those in the product line before. The distribution of electronic service centers makes customers save many electronic service center address and even customers have to find address who can repair his/her electronic. Many customers can't decide who can do a repair with good service so that customers will waste time, money and power because of difficult to choose the right electronic service center.

Seeing from the various problems above, a system that can help search for electronic service center based on customer locations, both large and small electronic service center, where is needed to make more practical transactions. Customers are given the convenience in determining which electronic service centers are more effective and do not have to save a lot of contacts where the electronic service center. This convenience will help customers to be able to do other activities, by not wasting time just to determine the location of electronic service centers. 


\section{LITERATURES REVIEW}

In Megha G. Mathpal's review, the distribution of popular places in India is not fully registered on the Internet [3]. Megha G. Mathpal makes a system that can display many of popular places based on the user's position. In designing the system, Haversine is used as a calculation of the distance between the user's position and various popular places. Next, a review from Farid and Yulanda Yunus developed a system to search for the closest location to hospitals and health centers in Gorontalo province [4]. The search system is helped by the Haversine method as a search for the closest location of the distribution of hospitals and health centers. Yulianto et al. discuss the application of the Haversine formula to search for the shortest distance to a futsal court location [5]. Yulianto et al. create a system for searching for the location of the nearest football court from the user's position. In the review of M. Basyir et al. explain about making a reporting application based on the user's location (example: police, hospital, etc.) using Haversine as a determinant of the user's distance [6]. From the four reviews above, the maps in the system uses the Google Maps API.

\section{FRAMEWORK}

This is a framework for information system marketplace for electronic repair service providers:

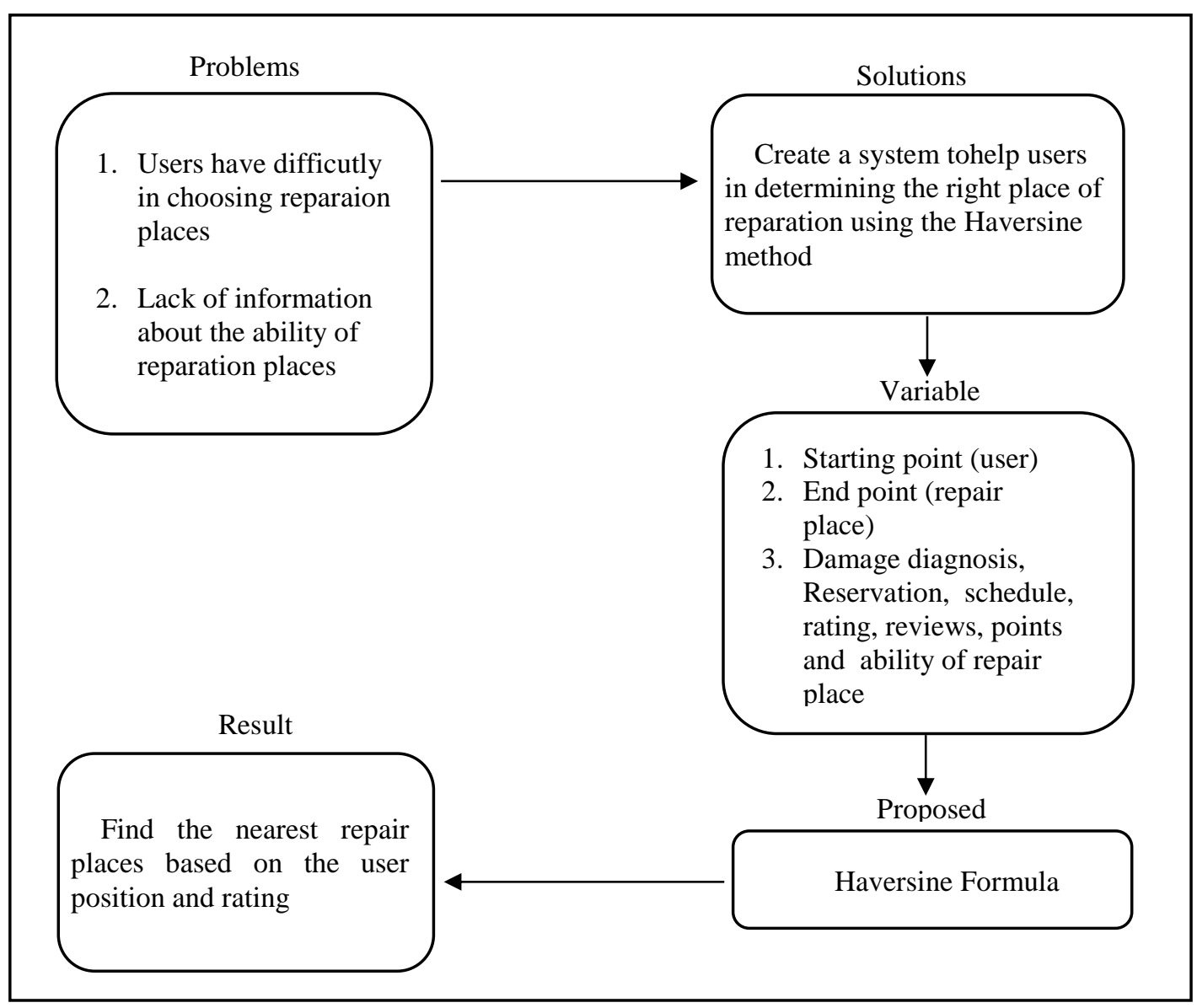

Fig. 1 Framework 
This system is designed using Unified Modeling Language (UML) which is software with the paradigm of "objectoriented". Modeling is actually used to simplify complex problems in such a way that it is easier to learn and understand [7]. Unified Modeling Language helps the system documentation process become easier and more efficient, UML consists of Use Case Diagrams, Activity Diagrams, Class Diagrams, and Sequence Diagrams. Therefore the following Use Case Diagram of the marketplace information system provider of electronic service centers:

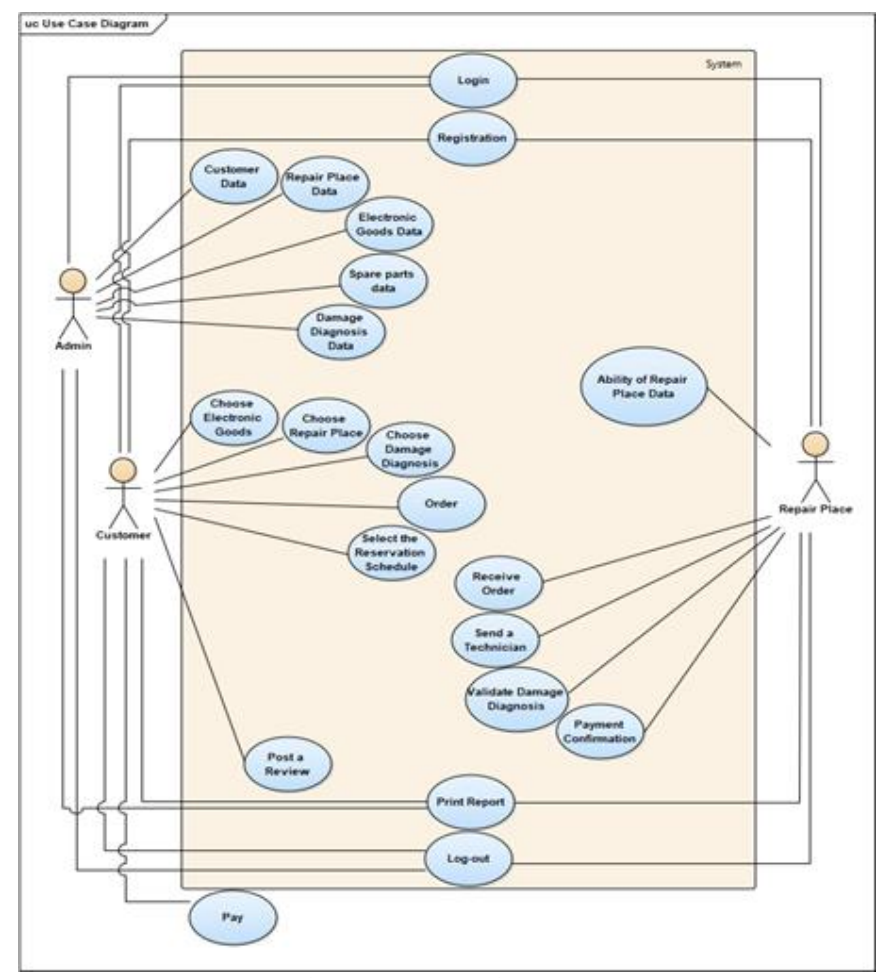

Fig. 2 Use Case Diagram

The following use cases are documented in the form of images for easy reading, the use case contains a collection of activities that occur in each actor both inside and outside the system. The system is designed using the Waterfall methodology. The Waterfall methodology is often called the sequential linear model or classic life cycle. The waterfall model provides an ordered lifeline approach starting from analysis, design, coding, testing, and maintenance [8]. In the first phase of analysis, Identifying problems that occur in customers and electronic repair places to be used as a foundation in making market information systems providers of reparation electronics services. at the Design stage, the system is designed using Unified Modeling Language (UML) modeling and the Haversine formula is used as a distance determination method. in the coding phase, the system is built using the PHP programming language and uses MySQL as a database. at the end of the testing phase, the system built will be tested by Black Box Testing: Boundary Value Analysis and User Acceptance Testing (UAT) as an assessment of the system of several respondents. With the Waterfall Methodology, the system design process becomes more systematic and orderly. Each stage will be more arranged, therefore the system designed can be completed properly.

The programming language used is using PHP and CSS as the design of the web, PHP \& CSS was choose because the system can be used through computers and smartphones. The database used is MySQL, the system programming is assisted by XAMPP as a server that connects the database with the web (localhost).

\section{METHODS}

Based on the problem proposed the Haversine Formula method as a calculation to find the distance of the user from the place of repair. Haversine Formula was first used by Josef de Mendoza y Ríos in 1795 [9]. In general, Haversine is used to calculate the distance between two points on earth based on the length of a straight line between two points without ignoring the curvature of the earth. Haversine requires latitude and longitude both positions of the start point and end point. 
The following is the Haversine Formula calculation formula:

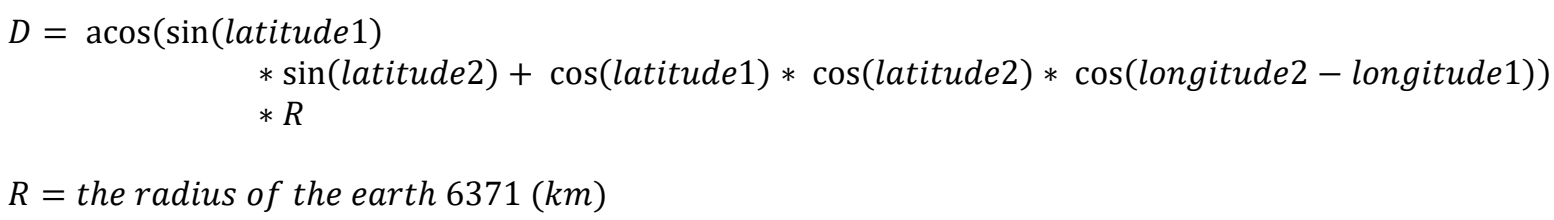

\section{RESUlts}

Furthermore, Haversine is calculated with the customer's location and several locations where the electronic service center:

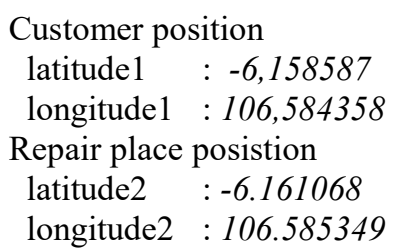

Before entering into the Haversine formulation, each latitude and longitude point of both positions is multiplied by radians.

$$
\begin{array}{ll}
\text { radian } & : 0,0174532925 \\
\text { radian latitude1 } & :-6,158587 * 0,0174532925 \\
& :-0,10748762 \\
\text { radian longitude1 } & : 106,584358 * 0,0174532925 \\
& : 1,860247976 \\
\text { radian latitude2 } & :-6,161068 * 0,0174532925 \\
& :-0,107530922 \\
\text { radian longitude2 } & : 106,585349 * 0,0174532925 \\
& : 1,860265272
\end{array}
$$

Next is the Haversine formulation:

$D=\operatorname{acos}(\sin ($ latitude 1$)$

\begin{tabular}{|c|c|c|c|c|c|}
\hline Places & Latitude & Longitude & Radian Latitude & Radian Longitude & Distance \\
\hline Customer & $-6,158587$ & 106,584358 & $-0,10748762$ & 1,860247976 & - \\
\hline Jawa Electronic & $-6,161068$ & 106,585349 & $-0,107530922$ & 1,860265272 & $\begin{array}{l}0,296832862 \mathrm{~km} \text { or } \\
296,8328619 \mathrm{~m}\end{array}$ \\
\hline Gino Service & $-6,153560$ & 106,578658 & $-0,107399883$ & 1,860148492 & $\begin{array}{l}0,842349093 \mathrm{~km} \text { or } \\
842,3490927 \mathrm{~m}\end{array}$ \\
\hline Saluyu Service & $-6,163337$ & 106,572465 & $-0,107571$ & 1,860040 & $\begin{array}{l}1,416925 \mathrm{~km} \text { or } \\
1416,925326 \mathrm{~m}\end{array}$ \\
\hline Mitra Jasa Elektronik & $-6,165968$ & 106,570313 & $-0,107616$ & 1,860003 & $\begin{array}{l}1,756275 \mathrm{~km} \text { or } \\
1756,275040 \mathrm{~m}\end{array}$ \\
\hline Rio Elektronik & $-6,181841$ & 106,593085 & $-0,107893479$ & 1,860400291 & $\begin{array}{l}2,759850908 \mathrm{~km} \text { or } \\
2759,850908 \mathrm{~m}\end{array}$ \\
\hline Servis Pak Mardi & $-6,186066$ & 106,613115 & $-0,107967$ & 1,860750 & $\begin{array}{l}4,409409 \mathrm{~km} \text { or } \\
4409,408767 \mathrm{~m}\end{array}$ \\
\hline
\end{tabular}

$$
* \sin (\text { latitude } 2)+\cos (\text { latitude } 1) * \cos (\text { latitude } 2) * \cos (\text { longitude } 2-\text { longitude } 1)) * R
$$

$D=\operatorname{acos}(\sin (-0,10748762)$

$* \sin (-0,107530922)$

$+\cos (1,860247976) * \cos (1,860265272) * \cos (1,860265272-1,860247976)) * 6371$

$D=0,296832862 \mathrm{~km}$ or $296,8328619 \mathrm{~m}$

Here are the results of the Haversine Formula calculation using customer and electronic service center repair points as sampling data to measure the closest distance:

Table I. Haversine Formula Calculations 
Next is Display of Select Electronic Service Center Location on the system:

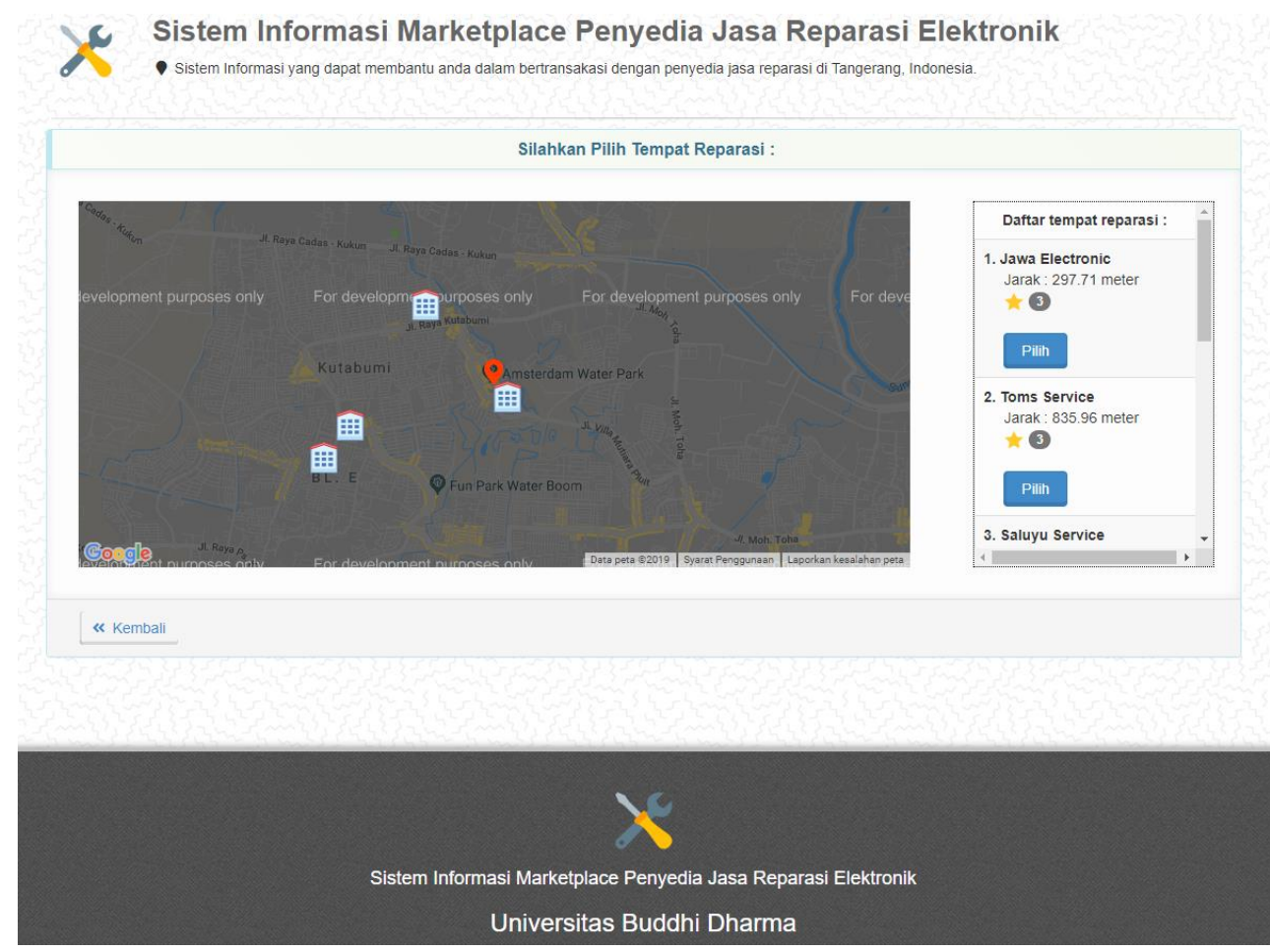

Fig. 3 Display of Select Electronic Service Center Location

The picture above is a display of select electronic service center location contained in the system, where there is a map and a list of electronic service center was available. The list of electronic service center has been sorted by the closest distance to the customer's position, rating, points, and ability of the repair shop.

\section{RESULT}

The search for repair is adjusted to the distance, rating, points, and ability of the repair places. Rating at each repair place is the result of reviews of orders that occurred at the repair place. The points here are used to indicate the activity of the reparation site, for the starting point will be given a value of 65 each electronic service center makes a registration. If the repair point is less than 45 , the repair shop cannot accept incoming bookings. Points will increase if the repair shop successfully performs repairs, while points will be reduced if the repair shop ignores or rejects customer bookings and can't repair customer electronic order. The following table values for each rating given in the form of points:

Table 2. The point value for rating

\begin{tabular}{|l|c|c|c|c|c|}
\hline Rating & $\star 1$ & $\star 2$ & $\star 3$ & $\star 4$ & $\star 5$ \\
\hline Point & -10 & -5 & +5 & +5 & +10 \\
\hline
\end{tabular}

Each rating entered when giving reviews on an electronic service center has its own point value. When customers submit reviews later each review will be added up and produce a rating of an electronic service center The ability of the electronic service center will be adjusted to the goods that can be repaired by the electronic service center. Because if not limited, the scope of electronic goods that can be repaired will be too broad.

In the customer system and the electronic service, can explain as shown below:

1. Service center must register, and check the suitability of the location point.

2. The electronic service center must register an electronice service center that can be repaired 
3. The customer can search for the electronic service center in accordance with the ability of the electronic service center. Search for electronic service center will also be sorted by the closest distance to the customer, rating, and have a minimum of 45 points.

4. The customer will choose a diagnosis that is in accordance with the condition of the electronic goods, if not available, customers can make a special order in the form of a description. Customers can continue the order or just to see the price of an electronic service center. If the customer continues the order, then customer will be asked to enter the reservation schedule with the electronic service center that was been selected.

5. The electronic service center can receive notification of the customer's order, but the electronic service center can reject the order if the electronic service center is not sure that it can repair the customer's electronic goods.

6. The electronic service center will send technicians according to the reservation schedule to the customer's location. The technician will validate the suitability of the damage diagnosis, if it is not appropriate the technician will update the customer's diagnosis.

7. After completion, the customer makes a payment for the technician's repair. Finally, customers will be asked to giving a review of the repairs carried out.

For test the feasibility of a system with Black Box Testing to test software in terms of functional specifications without testing the design and program code [10]. For that reason, Black Box Testing is tested using the Boundary Value Analysis technique, Boundary Value Analysis is a testing technique in Black Box Testing that tests an input value of upper and lower limits [11]. Upper limit value are 96,43 and the lower limit below are 96,88 is the length of the input. Boundary Value Analysis test of the two functionalities indicate that the system can handle data with a $96.66 \%$ success rate.

In a field. So that tested several functionalities of "Electronic Service Center Registration". Here is one of the results of system testing using the Boundary Value Analysis technique:

1) Electronic Service Center Registration

Electronic Service Center Registration is one of the functions performed by the electronic service center by entering the profile data and position of the electronic service center where it will be used to access the system. The Electronic Service Center Registration consists of a data entry form and a map of the electronic service center location. On this form there are seven data fields entered, namely: Username, Email, Password, Confirm password, Store name, Full address, and Repair fee.

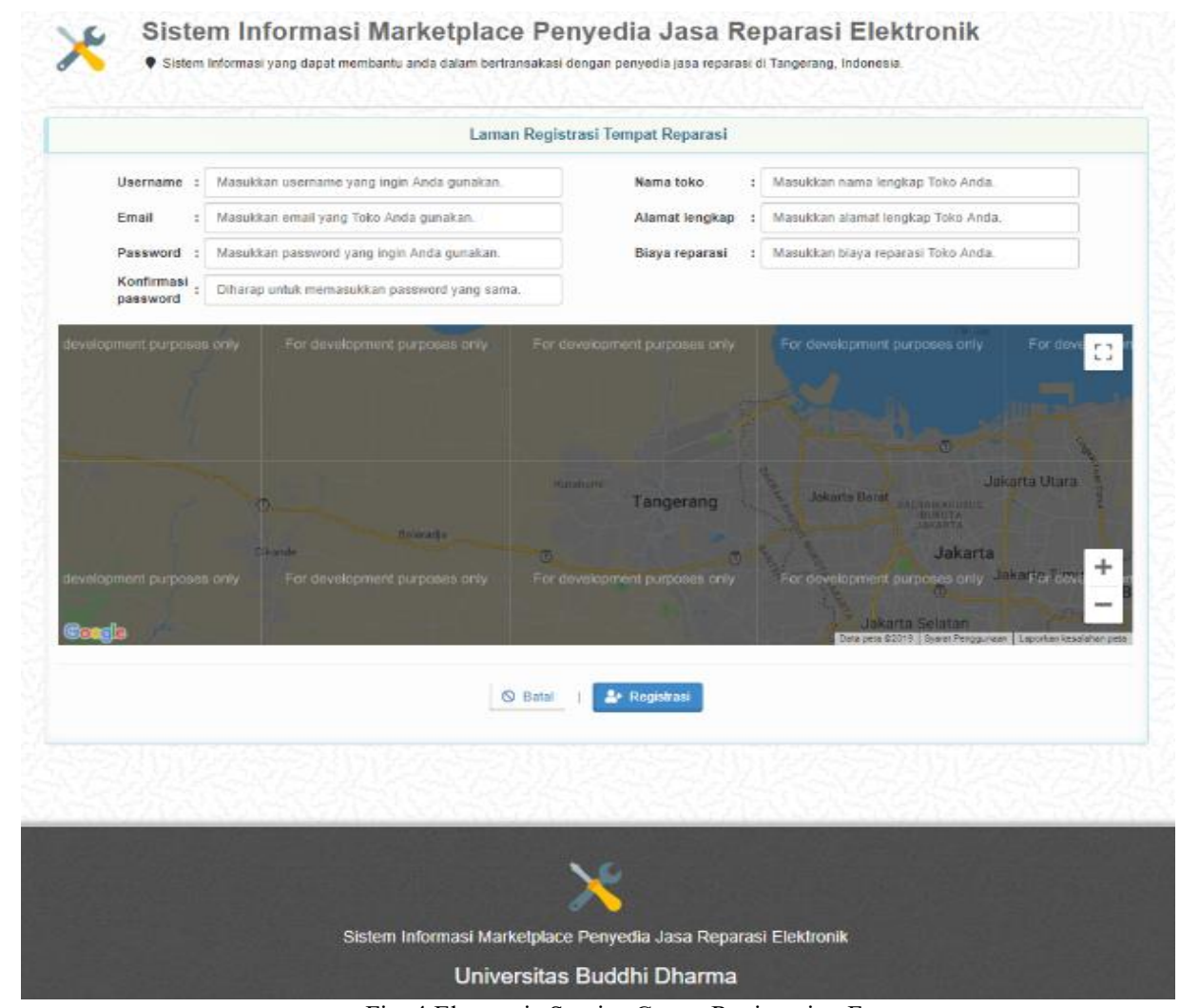

Fig. 4 Electronic Service Center Registration Form 
Based on the Customer Registration form (Figure 3.) an eight field-tested is carried out on the form and shown below.

Table 3. Testing of Customer Registration

\begin{tabular}{|c|c|c|c|c|c|}
\hline Field & Scope & Sample Data & $\begin{array}{l}\text { Estimated } \\
\text { Samples }\end{array}$ & Result & Conclusion \\
\hline \multirow[t]{4}{*}{ Username } & \multirow{4}{*}{$\begin{array}{l}\text { Consists of } 1 \\
\text { to } 20 \text { digits }\end{array}$} & - & False & False & Success \\
\hline & & $\mathrm{a}$ & True & True & Success \\
\hline & & aidenwilliamabhivany & True & True & Success \\
\hline & & aidenwilliamabhivanya & False & False & Success \\
\hline \multirow[t]{4}{*}{ Email } & \multirow{4}{*}{$\begin{array}{l}\text { Consists of } 1 \\
\text { to } 30 \text { digits }\end{array}$} & - & False & False & Success \\
\hline & & $\mathrm{a}$ & False & True & Failed \\
\hline & & $\begin{array}{c}\text { Aidenwilliamabhivany } \\
\text { @email.com }\end{array}$ & True & True & Success \\
\hline & & $\begin{array}{c}\text { Aidenwilliamabhivanya } \\
\text { @email.com }\end{array}$ & False & False & Success \\
\hline \multirow[t]{4}{*}{ Password } & \multirow{4}{*}{$\begin{array}{l}\text { Consists of } 1 \\
\text { to } 100 \text { digits }\end{array}$} & - & False & False & Success \\
\hline & & a & True & True & Success \\
\hline & & $\begin{array}{c}\text { \$2y\$10\$AfYyIEcy3Z4c } \\
\text { XO3NLi8bOeKFdpDmL } \\
\text { axmONDij6nXa.n.YZ.X } \\
\text { ZfOi2sOafY1KeOb8iLN3OXc41KsqZ } \\
\text { p2.\$s.dRtXZo }\end{array}$ & True & True & Success \\
\hline & & $\begin{array}{c}\text { \$2y\$10\$AfYyIEcy3Z4c } \\
\text { XO3NLi8bOeKFdpDmL } \\
\text { axmONDij6nXa.n.YZ.X } \\
\text { ZfOi2sOafY1KeOb8iLN3OXc4lKsqZ } \\
\text { p2.\$s.dRtXZoP }\end{array}$ & False & False & Success \\
\hline \multirow{4}{*}{$\begin{array}{l}\text { Password } \\
\text { Confirmatio } \\
\text { n }\end{array}$} & \multirow{4}{*}{$\begin{array}{l}\text { Consists of } 1 \\
\text { to } 100 \text { digits }\end{array}$} & - & False & False & Success \\
\hline & & $\mathrm{a}$ & True & True & Success \\
\hline & & $\begin{array}{c}\text { \$2y\$10\$AfYyIEcy3Z4c } \\
\text { XO3NLi8bOeKFdpDmL } \\
\text { axmONDij6nXa.n.YZ.X } \\
\text { ZfOi2sOafY1KeOb8iLN3OXc4lKsqZ } \\
\text { p2.\$s.dRtXZo }\end{array}$ & True & True & Success \\
\hline & & $\begin{array}{c}\text { \$2y\$10\$AfYyIEcy3Z4c } \\
\text { XO3NLi8bOeKFdpDmL } \\
\text { axmONDij6nXa.n.YZ.X } \\
\text { ZfOi2sOafY1KeOb8iLN3OXc4lKsqZ } \\
\text { p2.\$s.dRtXZoP }\end{array}$ & False & False & Success \\
\hline \multirow{4}{*}{$\begin{array}{l}\text { Customer } \\
\text { Name }\end{array}$} & \multirow{4}{*}{$\begin{array}{l}\text { Consists of } 1 \\
\text { to } 20 \text { digits }\end{array}$} & 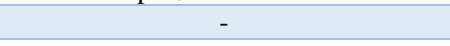 & False & False & Success \\
\hline & & $\mathrm{a}$ & True & True & Success \\
\hline & & Aiden Wiliam Abivana & True & True & Success \\
\hline & & Aiden Wiliam Abivanya & False & False & Success \\
\hline \multirow{4}{*}{$\begin{array}{l}\text { Customer } \\
\text { Birthdate }\end{array}$} & \multirow[t]{4}{*}{ age $>18$} & - & False & False & Success \\
\hline & & $1997-05-10$ & True & True & Success \\
\hline & & $2001-12-31$ & True & True & Success \\
\hline & & 2002-01-01 & False & False & Success \\
\hline \multirow[t]{4}{*}{ Gender } & \multirow{4}{*}{$\begin{array}{l}\text { Consists of } 1 \\
\text { to } 6 \text { digits }\end{array}$} & - & False & False & Success \\
\hline & & W & True & True & Success \\
\hline & & Wanita & True & True & Success \\
\hline & & Wanita1 & False & False & Success \\
\hline \multirow{4}{*}{$\begin{array}{l}\text { Customer } \\
\text { Full Address }\end{array}$} & \multirow{4}{*}{$\begin{array}{l}\text { Consists of } 1 \\
\text { to } 6 \text { digits }\end{array}$} & - & False & False & Success \\
\hline & & $\mathrm{J}$ & True & True & Success \\
\hline & & $\begin{array}{c}\text { Jalan Kavling Perkebunan Raya } \\
\text { \#C225B21, Panunggangan Barat, } \\
\text { Cibodas, Panunggangan Bar., Kec. } \\
\text { Cibodas, Kota Tangerang, Banten } \\
15139\end{array}$ & True & True & Success \\
\hline & & $\begin{array}{l}\text { Jalan Kavling Perkebunan Raya } \\
\text { \#C225B21A, Panunggangan Barat, } \\
\text { Cibodas, Panunggangan Bar., Kec. } \\
\text { Cibodas, Kota Tangerang, Banten } \\
15139\end{array}$ & False & False & Success \\
\hline
\end{tabular}


Table 4. Testing Result (Customer Registratiion)

\begin{tabular}{|l|l|r|r|r|}
\hline \multirow{2}{*}{ No } & Field & Success & Failed & \multicolumn{2}{c|}{$\begin{array}{l}\text { Success Rate } \\
(\%)\end{array}$} \\
\hline $\mathbf{1}$ & Username & 4 & 0 & 100 \\
\hline $\mathbf{2}$ & Email & 3 & 1 & 75 \\
\hline $\mathbf{3}$ & Password & 4 & 0 & 100 \\
\hline $\mathbf{4}$ & Password Confirmation & 4 & 0 & 100 \\
\hline $\mathbf{5}$ & Customer Name & 4 & 0 & 100 \\
\hline $\mathbf{6}$ & Customer Birthdate & 4 & 0 & 100 \\
\hline $\mathbf{7}$ & Gender & 4 & 0 & 100 \\
\hline $\mathbf{8}$ & Customer Full Address & 4 & 0 & 100 \\
\hline & & & & 96,88 \\
\hline
\end{tabular}

The table above shows that the "Customer Registration" functionality can handle data $96.88 \%$.

Based on the Electronic Service Center Registration form (Figure 4.) a seven field-tested is carried out on the form and shown below.

Table 5. Testing of Electronic Service Center Registration

\begin{tabular}{|c|c|c|c|c|c|}
\hline Field & Scope & Sample Data & $\begin{array}{l}\text { Estimated } \\
\text { Samples }\end{array}$ & Result & Conclusion \\
\hline \multirow[t]{4}{*}{ Username } & \multirow{4}{*}{$\begin{array}{l}\text { Consists of } 1 \\
\text { to } 20 \text { digits }\end{array}$} & & False & False & Success \\
\hline & & $\mathrm{a}$ & True & True & Success \\
\hline & & Aidenwilliamabhivany & True & True & Success \\
\hline & & aidenwilliamabhivanya & False & False & Success \\
\hline \multirow[t]{4}{*}{ Email } & \multirow{4}{*}{$\begin{array}{l}\text { Consists of } 1 \\
\text { to } 30 \text { digits }\end{array}$} & & False & False & Success \\
\hline & & $\mathrm{a}$ & False & True & Failed \\
\hline & & $\begin{array}{l}\text { Aidenwilliamabhivany } \\
\text { @email.com }\end{array}$ & True & True & Success \\
\hline & & $\begin{array}{l}\text { Aidenwilliamabhivanya } \\
\text { @email.com }\end{array}$ & False & False & Success \\
\hline \multirow[t]{4}{*}{ Password } & \multirow{4}{*}{$\begin{array}{l}\text { Consists of } 1 \\
\text { to } 20 \text { digits }\end{array}$} & & False & False & Success \\
\hline & & admin & True & True & Success \\
\hline & & adminadminadminadmin & True & True & Success \\
\hline & & adminadminadminadmin1 & False & False & Success \\
\hline \multirow{4}{*}{$\begin{array}{l}\text { Password } \\
\text { Confirmatio } \\
\text { n }\end{array}$} & \multirow{4}{*}{$\begin{array}{l}\text { Consists of } 1 \\
\text { to } 20 \text { digits }\end{array}$} & & False & False & Success \\
\hline & & admin & True & True & Success \\
\hline & & adminadminadminadmin & True & True & Success \\
\hline & & adminadminadminadmin1 & False & False & Success \\
\hline \multirow[t]{4}{*}{ Store name } & \multirow{4}{*}{$\begin{array}{l}\text { Consists of } 1 \\
\text { to } 35 \text { digits }\end{array}$} & & False & False & Success \\
\hline & & Mitra & True & True & Success \\
\hline & & MitraJasaElektronik Service First & True & True & Success \\
\hline & & MitraJasaElektronik Service First1 & False & False & Success \\
\hline \multirow[t]{4}{*}{ Full address } & \multirow{4}{*}{$\begin{array}{l}\text { Consists of } 1 \\
\text { to } 130 \text { digits }\end{array}$} & & False & False & Success \\
\hline & & Jalan & True & True & Success \\
\hline & & $\begin{array}{l}\text { JalanKavling Perkebunan Raya } \\
\text { \#C225B21, Panunggangan Barat, } \\
\text { Cibodas, Panunggangan Bar., Kec. } \\
\text { Cibodas, Kota Tangerang, Banten } \\
15139\end{array}$ & True & True & Success \\
\hline & & $\begin{array}{c}\text { JalanKavling Perkebunan } \\
\text { Raya\#C225B21A, Panunggangan } \\
\text { Barat, Cibodas, PanungganganBar., } \\
\text { Kec. Cibodas, Kota Tangerang, } \\
\text { Banten } 15139\end{array}$ & False & False & Success \\
\hline \multirow[t]{4}{*}{ Repair Fee } & \multirow{4}{*}{$\begin{array}{l}\text { Consists of } 1 \\
\text { to } 6 \text { digits }\end{array}$} & & False & False & Success \\
\hline & & 1 & True & True & Success \\
\hline & & 100000 & True & True & Success \\
\hline & & 1000000 & False & False & Success \\
\hline
\end{tabular}




\begin{tabular}{|c|c|c|c|c|}
\hline \multirow[t]{2}{*}{ No } & \multirow[t]{2}{*}{ Field } & \multicolumn{2}{|c|}{ Trial } & \multirow{2}{*}{$\begin{array}{r}\text { Success } \\
\text { Rate }(\%)\end{array}$} \\
\hline & & Success & Failed & \\
\hline 1 & Username & 4 & 0 & 100 \\
\hline 2 & Email & 3 & 1 & 75 \\
\hline 3 & Password & 4 & 0 & 100 \\
\hline 4 & Password Confirmation & 4 & 0 & 100 \\
\hline 5 & Store Name & 4 & 0 & 100 \\
\hline 6 & Full Address & 4 & 0 & 100 \\
\hline 7 & Repair Fee & 4 & 0 & 100 \\
\hline \multicolumn{4}{|c|}{ Average } & 96,43 \\
\hline
\end{tabular}

The table above shows that the "Electronic Service Center Registration" functionality can handle data 96.43\%.

2) Overall Boundary Value Analysis

Here is a summary table of the entire Boundary Value Analysis to see the percentage of success of each functionality tested in handling data:

Table 7. Recapitulation Result

\begin{tabular}{|c|l|c|}
\hline No & \multicolumn{1}{|c|}{ Functionality } & $\begin{array}{c}\text { Success } \\
\text { Rate (\%) }\end{array}$ \\
\hline $\mathbf{1}$ & Customer Registration & 96,88 \\
\hline $\mathbf{2}$ & $\begin{array}{l}\text { Electronic Service Center } \\
\text { Registration }\end{array}$ & 96,43 \\
\hline \multicolumn{2}{|c|}{ Average } & 96,66 \\
\hline
\end{tabular}

Based on the table above, it can be concluded that the results of the Boundary Value Analysis test of the two functionalities indicate that the system can handle data with a $96.66 \%$ success rate. one field in the "Customer Registration" functionality and one field in the "Electronic Service Center Registration" functionality needs to be improved to improve the system's ability to process data.

In processing the data using descriptive statistical analysis. Descriptive statistical analysis describe the facts that there is to be processed into data. The data then analyzed to obtain a conclusion. Descriptive statistical analysis used to describe how the quality level application system.

The steps performed in the descriptive statistical analysis are as follows:

a. Each indicator is rated by the respondents, classified into five alternative answers using ordinal scale that describes rank answers.

b. Calculate total score variable/subvariable $=$ total score of all indicator variable for all respondents.

c. Calculate score every variable/subvariable $=$ average from total score.

d. To describe the respondents' answers, also used descriptive statistics such as frequency distribution and display in the form of tables or graphs.

e. To answer a description of the variables, use a range of assessment criteria as follows:

$$
\text { Actual Score }=\frac{\text { Actual Score }}{\text { Ideal Score }} \times 100 \%
$$

Actual Score $=$ All respondent answer

Ideal score $=$ Highest score or all respondents assumed to choose the answer with the highest score

Table 8. Ideal Percentage Criteria Score [12]

\begin{tabular}{|l|l|}
\hline \% Total Score & Bad \\
\hline $\mathbf{2 0 , 0 0 \%}-\mathbf{3 6 , 0 0 \%}$ & Not Good \\
\hline $\mathbf{3 6 , 0 1 \%} \mathbf{- 5 2 , 0 0 \%}$ & Enough \\
\hline $\mathbf{5 2 , 0 1 \%}-\mathbf{6 8 , 0 0 \%}$ & Good \\
\hline $\mathbf{6 8 , 0 1 \%} \mathbf{- 8 4 , 0 0 \%}$ & Very Good \\
\hline $\mathbf{8 4 , 0 1 \%}-\mathbf{1 0 0 \%}$ & \\
\hline
\end{tabular}




\section{CONCLUSIONS}

Based on the results of the marketplace information system design of an electronic repair service provider, it can be concluded as follows:

1) The Haversine method helps calculate the distance between each customer position and the scattered repair places

2) The search for repair places is also adjusted to the ability to repair electronic goods so that the process of finding a repair place becomes more effective and efficient

3) The existence of ratings and review on repair place can help new customers make an order

4) The information system that was designed have $96.66 \%$ success rate of receiving data in the Boundary Value Analysis test

5) User Acceptance Testing method test system on 15 respondents in the form of a questionnaire containing 10 questions about the system with results $75.86 \%$ agree.

\section{REFERENCES}

[1] C. Ahmadi and D. Hermawan, E-Business \& E-Commerce, Yogyakarta: Andi, 2013..J. Clerk Maxwell, A Treatise on Electricity and Magnetism, 3rd ed., vol. 2. Oxford: Clarendon, 1892, pp.68-73.

[2] Y. D. Handarkho, T. R. Suryanto, F. K. S. Dewi and E. Julianto, "Penerapan Strategi E-business Untuk Meningkatkan Keunggulan Kompetitif dari Usaha Mikro Kecil Menengah di Indonesia (Studi kasus Trooper Electronic Yogyakarta)," Jurnal Buana Informatika, pp. 201-212, 2017.

[3] M. G. Mathpal, "A Landmark Based Shortest Path Detection by Using A* and Haversine Formula," International Journal on Recent and Innovation Trends in Computing and Communication, vol. 6, no. 7, pp. 98-101, 2018.

[4] F. and Y. Yunus, "Analisa Algorima Haversine Formula untuk Pencarian Lokasi Terdekat Rumah Sakit Dan Puskesmas Provinsi Gorontalo," ILKOM Jurnal Ilmiah, vol. 9, no. 3, pp. 353-355, 2017.

[5] Y. R. and A. H. Kridalaksana, "Penerapan Formula Haversine Pada Sistem Informasi Geografis Pencarian Jarak Terdekat Lokasi Lapangan Futsal," Informatika Mulawarman : Jurnal Ilmiah Ilmu Komputer, vol. 13, no. 1, pp. 14 - 21, 2018.

[6] M. Basyir, M. Nasir, S. and W. Mellyssa, "Determination of Nearest Emergency Service Office using," EMITTER International Journal of Engineering Technology, vol. 5, no. 2, pp. 270-278, 2017.

[7] A. Nugroho, Rekayasa Perangkat Lunak Berorientasi Objek Dengan Metode USDP (Unified Software Development Process), Yogyakarta: Andi Offset, 2010

[8] R. A. Sukamto and M. Shalahuddin, Rekayasa Perangkat Lunak Terstruktur dan Berorientasi Objek, Bandung: Informatika, 2014.

[9] J. d. M. y. Rios, Memoria sobre algunos métodos nuevos de calcular la longitud por las distancias lunares: y aplication de su teórica á la solucion de otros problemas de navegacion, Madrid: Imprenta Real, 1795.

[10] R. Amin, "Rancang Bangun Sistem Informasi Penerimaan Siswa Baru Pada SMK Budhi Warman 1 Jakarta," Jurnal Ilmu Pengetahuan Dan Teknologi Komputer, vol. 2, no. 2, pp. 113-121, 2017.

[11] T. S. Jaya, "Pengujian Aplikasi dengan Metode Blackbox Testing (Studi Kasus: Kantor Digital Politeknik Negeri Lampung)," Jurnal Informatika: Jurnal Pengembangan IT (JPIT), vol. 3, no. 2, pp. 45-48, 2018.

[12] Narimawati, Umi. 2008, 'Metodologi Penelitian Kualitatif dan Kuantitatif, Teori dan Aplikasi', Bandung, Agung Media. 